\title{
O instituto da delação premiada como forma de obtenção da verdade
}

\author{
The institute of plea deal as a way of obtaining the truth \\ Samara Pereira ALVES* \\ Universidade Estadual do Sudoeste da Bahia (UESB) \\ Edvania Gomes da SILVA** \\ Universidade Estadual do Sudoeste da Bahia (UESB)
}

\begin{abstract}
RESUMO: Neste artigo, mostramos como o instituto jurídico da delação premiada funciona como uma forma de obtenção da verdade. Para tanto, em um primeiro momento, recorremos a Foucault para apresentar, brevemente, o funcionamento de diferentes formas de obtenção da verdade jurídica na história. Em seguida, mostramos de que forma a delação premiada é discursivizada nas diferentes leis que tratam do referido instituto ou que o retomam, relacionando-o com outras leis e fazendo-o funcionar como uma forma de obtenção da verdade, vinculada, principalmente, ao inquérito. $\mathrm{Na}$ análise das referidas leis, identificamos os deslizamentos de sentido que ocorrem tanto no que diz respeito à figura do delator, quanto em relação a constituição histórica do referido instituto.
\end{abstract}

PALAVRAS-CHAVE: Delação. Discursivização. Verdade. Memória. Delator.

\begin{abstract}
In this article, we show how the legal institute of plea deal works as a way to obtain the truth. In order to do so, at first, we turn to Foucault to present, briefly, operationally how different ways of obtaining legal truth in history works. Next, we show how the plea deal is discursive in the different laws that refers to this institute or that take it back, relating it to other laws and making it work as a way of obtaining the truth, linked, mainly, to the investigation. During the analysis of these laws, we identify the deviations of meaning that occurs either in which is related to the state's witness, as well as in relation to the historical constitution of referred institute.
\end{abstract}

KEYWORDS: Plea Deal. Discursive. Truth. Memory. State's Witness.

\section{Introdução}

Neste artigo, analisamos o instituo negocial penal da delação premiada e a relação desse instituto com a memória acerca das formas de obtenção da verdade. Nesse sentido, a pergunta/problema que direcionou a construção deste texto foi: qual memória o instituto negocial penal da delação premiada retoma? Com base nessa pergunta-

\footnotetext{
* Graduada em Direito. Discente do Programa de Pós-Graduação em Memória: Linguagem e Sociedade, da Universidade Estadual do Sudoeste da Bahia - UESB, Vitória da Conquista, Bahia, Brasil. e-mail: samarapalves@hotmail.com.

** Doutora em Linguística. Professora Titular do DELL/UESB e do Programa de Pós-Graduação em Memória: Linguagem e Sociedade (PPGMLS), da Universidade Estadual do Sudoeste da Bahia - UESB, Vitória da Conquista, Bahia, Brasil. e-mail: edvaniagsilva@gmail.com.
} 
problema, estabelecemos os seguintes objetivos: i) verificar qual memória ou efeitos de memória o instituto negocial penal da delação premiada retoma; e ii) mostrar que o instituto da delação premiada funciona como uma forma de aferição da verdade jurídica. Para tanto, em um primeiro momento, buscamos caracterizar historicamente o referido instituto e mostrar que o mesmo passou por várias (re)configurações até chegar a seu formato atual. Em um segundo momento, verificamos os diferentes efeitos de sentido relacionados à figura do sujeito delator. Para tanto, analisamos as leis que tratam da delação premiada, recorrendo, para isso, aos trabalhos das Escola Francesa de Análise de Discurso e, mais precisamente, ao conceito de memória discursiva, conforme apresentado nos trabalhos de Pêcheux [1990, 1993, 1999]. Tal análise nos possibilitou demonstrar que a figura do delator vai sendo construída e reconstruída num jogo entre memória e atualidade.

\section{As formas de obtenção da verdade jurídica na história}

Neste tópico, caracterizamos historicamente o instituto jurídico da delação premiada. Para tanto, mostramos a constituição de algumas formas de obtenção da verdade judicial na história, sem nos preocuparmos com aspectos cronológicos e/ou evoluções temporais. Nesse sentido, partimos de uma análise histórica seguindo a proposta de Foucault (2005), o qual defende que a história se depreende das categorizações prévias em épocas, períodos, e outras mais classificações. Trata-se de uma história serial que se opõe ao que Foucault chama de história tradicional.

Nessa perspectiva, buscamos, nesse tópico, com base em Foucault (2002), apresentar a história do instituto da delação premiada, sem vinculá-lo, contudo, a um passado e/ou a uma noção de tempo cronológico, mas analisando-o a partir da relação entre mudança e acontecimento. Dessa forma, buscamos mostrar que existe uma história da verdade, como defende Foucault (2002), e que a mesma se articula com as mudanças ocorridas nas condições de possibilidade ${ }^{1}$ de cada período histórico, constituindo assim novos acontecimentos, no sentido foucaultiano do termo ${ }^{2}$. Assim, a história com a qual

\footnotetext{
${ }^{1}$ Neste artigo, a noção de "condições de possibilidade" é usada no sentido foucaultiano do termo. Para esse autor, se, por um lado, o homem ocupa o papel de sujeito da enunciação, por outro, são as práticas discursivas que definem as condições de possibilidade para que o enunciado possa surgir e ser validado.

${ }^{2}$ De acordo com Foucault (2005), os acontecimentos devem ser pensados com base numa concepção de história serial, a qual, ainda segundo o referido autor, "permite de qualquer forma fazer aparecer
} 
trabalhamos aqui está fundamentada nas análises das transformações ocorridas para obtenção da verdade jurídica e na relação lógica entre diferentes elementos dessas formas de verdades, sendo possível construir um emaranhado de descontinuidades sobrepostas.

Com base nessa perspectiva, no livro a Verdade e as formas jurídicas, Foucault (2002) apresenta um novo método para analisar a história do que chama de formas jurídicas, buscando mostrar a relação entre os acontecimentos. O livro é organizado em cinco conferências, nas quais o autor apresenta diferentes objetos, bem como mostra a relação desses objetos com um campo mais vasto, trazendo diversas variáveis que, segundo ele, deveriam ser consideradas.

$\mathrm{Na}$ primeira conferência, o autor discute as práticas sociais que produzem um novo saber jurídico para a formação da verdade, bem como mostra o surgimento de novos sujeitos de conhecimento. Ainda segundo Foucault (2002), entre os lugares em que a verdade se forma e as diversas regras do jogo, as práticas penais seriam o ponto de partida para a obtenção da relação entre o homem e a verdade. Ele acrescenta, ainda, que o inquérito policial é uma forma característica da verdade em nossa sociedade, pois surge como uma maneira de pesquisar tal verdade.

Na segunda conferência, o autor trabalha a tragédia de Édipo. Essa tragédia é apresentada como um ponto de emergência do inquérito e como um episódio relevante da história do saber, pois, para Foucault, existe uma relação intrínseca entre os efeitos de verdade que uma sociedade produz e os jogos de saber/poder. Em uma entrevista gravada em Paris, no dia 13 de outubro de 1977, o referido autor, tratando da relação entre poder e saber, afirma que:

Essas produções de verdade não podem ser dissociadas do poder e dos mecanismos de poder, ao mesmo tempo porque esses mecanismos de poder tornam possíveis, induzem essas produções de verdades, e porque essas produções de verdade têm, elas próprias, efeitos de poder que no unem, nos atam. São essas relações verdade/poder, saber/poder que me preocupam” (FOUCAULT, 2006, p. 229).

diferentes estratos de acontecimentos, dos quais uns são mais visíveis, imediatamente conhecidos até pelos contemporâneos, e em seguida, debaixo desses, acontecimentos que são de qualquer forma a espuma da história, há outros acontecimentos invisíveis, imperceptíveis para os contemporâneos, e que são de um tipo completamente diferente. /.../. Cabe ao historiador descobrir esse estrato escondido de acontecimentos difusos, 'atmosféricos', policéfalos que, afinal, determinam, e profundamente, a história do mundo" (FOUCAULT, 2005, p. 292). 
Ainda segundo o autor, a tragédia de Édipo apresenta o mecanismo das metades, o qual serve para construir a verdade por meio de um mágico exercício do poder ${ }^{3}$. Isso mostra que a verdade não é mais obtida com base em uma disputa para ver quem tem mais força física; essa "verdade" passa ser obtida a partir de um saber, que não é jamais unificado, já que está dividido em, ao menos, duas metades.

$\mathrm{Na}$ terceira conferência, Foucault trata do desenvolvimento do inquérito na sociedade grega e mostra que, após um longo processo de mudanças, o judiciário grego conquistou o direito à testemunha. A produção da verdade contava agora com a filosofia, os sistemas racionais e os sistemas científicos. Havia uma elaboração da arte de persuadir, de convencer as pessoas da verdade. Em contrapartida, o lado que é investigado também se preocupa com o poder de persuadir, de convencer as pessoas de sua própria verdade, produzindo, assim, a chamada retórica grega. Foucault (2002) afirma, então, que surge assim um novo tipo de conhecimento, um conhecimento voltado para o testemunho, para as lembranças e, portanto, para o inquérito. A história do surgimento do inquérito ficou esquecida e retornou de outras maneiras, alguns séculos depois, na Idade Média. Nesta fase da Idade Média, ocorreu, ainda segundo Foucault (2002), um segundo nascimento do inquérito, mais lento e obscuro, porém mais eficaz que o primeiro, assumindo, assim, grandes dimensões. Esse inquérito da Idade Média era uma prática penal que tinha por objetivo investigar um ato errôneo praticado pelo sujeito, as condições desse ato e o momento em que essa conduta ocorreu. Dessa forma, o inquérito passou a ser considerado como uma forma de saber, a qual permitia acesso à verdade que prevaleceria naquele litígio e conforme aquelas circunstâncias. Nesse sentido, como defende Foucault (2006), a aferição da verdade mantém, portanto, uma relação íntima com a produção de saber-poder.

Na quarta conferência, Foucault (2002) mostra que, no final do século XVIII e início do século XIX, acontece a formação da sociedade disciplinar. Isso ocorre com reorganização do sistema judiciário e penal em diversos países da Europa e do mundo.

\footnotetext{
${ }^{3} \mathrm{O}$ mecanismo da metade é, segundo Foucault, "um instrumento de poder, de exercício de poder, que permite a alguém que detém um segredo ou um poder quebrar em duas partes um objeto qualquer, de cerâmica, etc..., guardar uma das partes e confiar a outra parte a alguém que deve levar a mensagem ou atestar sua autenticidade. É pelo ajustamento destas duas metades que se poderá reconhecer a autenticidade da mensagem, isto é, a continuidade do poder que se exerce. O poder se manifesta, completa seu ciclo, mantém sua unidade graças a este jogo de pequenos fragmentos, separados uns dos outros, de um mesmo conjunto, de um único objeto, cuja configuração geral é a forma manifesta do poder" (FOUCAULT, 2002, p. 38).
} 
Vale salientar que, quando trata dessa sociedade disciplinar, Foucault (2002) se refere a uma sociedade em que o poder era exercido sob os indivíduos de maneira específica, sendo então uma forma de poder que "se exerce sobre os indivíduos em forma de vigilância individual e contínua, em forma de controle de punição e recompensa, em forma de correção, isto é, de formação e transformação de indivíduos em função de certas normas" (FOUCAULT, 2002, p. 103).

Nessa conferência, Foucault, trata também da nova definição de sujeito criminoso. O criminoso passa a ser visto, a partir de então, não mais como somente aquele que danifica e perturba, mas principalmente como aquele que é inimigo da sociedade. Com isso, surge a necessidade de uma forma de tratamento da lei penal perante esse indivíduo criminoso. Nesse momento, a lei penal passa a atender não mais os princípios religiosos, mas visa apagar o dano causado pelo indivíduo à sociedade.

Na quinta conferência, Foucault mostra o crescimento do processo de vigilância. Trata-se, mais especificamente, de verificar como se desenvolveu um controle do indivíduo que se estende ao longo da existência do sujeito, dando lugar ao surgimento das Ciências Humanas, como a Sociologia e a Psicologia. Esse foi, portanto, o momento em que uma sociedade de vigilância começou a se desenvolver e a trazer inovações às formas de aferição da verdade. É nesse sentido que Foucault, no final da última conferência, defende que:

O sub-poder, condição do sobre-lucro, ao se estabelecer, ao passar a funcionar, provocou o nascimento de uma série de saberes - saber do indivíduo, da normalização, saber corretivo - que se multiplicaram nestas instituições de sub-poder fazendo surgir as chamadas ciências do homem e o homem como objeto da ciência (FOUCAULT, 2002, p. 125)

Em síntese, em A verdade e as formas jurídicas, Foucault apresenta uma história descontínua das diferentes formas de aferição da verdade. Partindo, portanto, desse livro, neste artigo, defendemos que a delação premiada funciona, na atualidade, como uma forma de aferição da verdade que está relacionada tanto com o inquérito, quanto com aquilo que surge a partir do final do século XIX: o exame. O exame consiste em uma forma de "poder epistemológico, poder de extrair dos indivíduos um saber e extrair um saber sobre estes indivíduos submetidos ao olhar e já controlados por diferentes poderes" (FOUCAULT, 2002, p. 121). Essa extração de um saber sobre os indivíduos se dá, ainda segundo Foucault (2002), de duas maneiras: i) por meio de um saber 
tecnológico, como aquele que se exerce nas/pelas instituições de sequestro, como as fábricas e as prisões, onde se aprende sobre o trabalhador ou sobre o preso a partir da observação de suas práticas cotidianas; ou ii) por meio de um saber que nasce da observação dos indivíduos, da análise de seus comportamentos, o que ocorre com base em uma análise clínica deste indivíduo, como o fazem a psiquiatria, a psicologia, etc.

\section{A delação premiada como forma de aferição de verdades}

Neste artigo, partindo do que apresenta Foucault acerca das formas jurídicas, estamos considerando o instituto da delação premiada como uma forma de aferição da verdade que, associada ao inquérito e ao exame, diz muito sobre o funcionamento da sociedade e também sobre as relações de saber-poder que se estabelecem na contemporaneidade.

A delação premiada consiste em benefícios oferecidos pelo Estado àquele que colabora de maneira eficaz e voluntária para o esclarecimento do fato delituoso e para a possível construção da verdade judicial. Isso permite que, com as informações do delator acerca das práticas delituosas promovidas pelo grupo criminoso, seja possível localizar a vítima, recuperar produtos do crime ou mesmo identificar outros envolvidos (MOSSIN; MOSSIN, 2016). Nessa perspectiva, a delação premiada "consiste na afirmativa feita por um acusado, ao ser interrogado em juízo ou ouvido na polícia. Além de confessar a autoria de um fato criminoso, igualmente atribui a um terceiro a participação como seu comparsa" (CAPEZ, 2010, p. 255). O "prêmio" conseguido por meio da delação pode ser a redução da pena, o perdão judicial ou mesmo a aplicação de regime penitenciário mais brando. Nesse sentido, quanto mais informações forem fornecidas, maior será o benefício. Salientamos, ainda, que a confissão da delação premiada difere da confissão comum, pois essa refere-se à autoincriminação, enquanto aquela, a confissão delatória, diz respeito à imputação de fato(s) criminoso(s) a terceiros.

Para que esse instituto não seja utilizado pelo delator para atribuir conduta delituosa a um inocente, como uma forma de conseguir o benefício de qualquer maneira, é importante ressaltar que esse relato não servirá como prova absoluta contra aquele a que o delator imputou a prática criminosa. Dessa forma, a delação é utilizada apenas como um instrumento indicador de materialidade e de autoria do crime, 
permitindo, assim, que se abra caminho para novas provas (MOSSIN; MOSSIN, 2016).

Tal instituto surgiu diante das dificuldades encontradas para se punir os crimes praticados em concurso de agentes. Concurso de agentes são várias pessoas, em convergência de vontades, participando da realização de um delito. Nesse sentido, a delação premiada funciona como uma forma de suprir uma parte da investigação que o Estado não consegue realizar. A prática criminosa do concurso de agentes tem requerido muita atenção por parte dos agentes da lei, pois tem sido uma prática bastante frequente e cada vez mais crescente. O Estado, como responsável pela segurança dos indivíduos, tem o dever de prevenir e repreender esse tipo de organização. Nesse sentido, a delação premiada foi uma saída encontrada pelo Estado para combater a organização criminosa, garantindo ao delator uma oportunidade de negociação. Com essa oportunidade, o Estado consegue suprir sua carência na investigação dos crimes cometidos por essas organizações, uma vez que, sem a delação, muitos fatos delituosos não seriam descobertos por falta de pistas.

\section{A relação entre memória e atualidade nos trabalhos de Pêcheux}

Neste tópico, recorremos à Escola Francesa de Análise de Discurso e, mais precisamente, ao conceito de memória discursiva, conforme apresentado nos trabalhos de Pêcheux, para, em seguida, mostrarmos como a figura do delator vai sendo construída e reconstruída num jogo entre memória e atualidade.

O livro Papel da memória é uma obra composta por quatro textos em que a memória é trabalhada sob diferentes aspectos. Nessa perspectiva, por meio da análise de diferentes formas de constituição da memória, a referida obra mostra como a memória pode funcionar em diferentes disciplinas e sob diferentes perspectivas teóricas.

No texto escrito por Pêcheux, cujo título é Papel da memória, título homônimo ao do livro, o referido autor afirma que as conferências proferidas pelos demais autores (o livro é o resultado de uma sessão temática realizada na Escola Normal Superior de Paris, em abril de 1983) mostraram "as condições (mecanismos, processos...) nas quais um acontecimento histórico (um elemento histórico descontínuo e exterior) é suscetível de vir a se inscrever na continuidade interna, no espaço potencial de coerência próprio a uma memória" (PÊCHEUX, 1999, p. 49-50). Trata-se, portanto, de mostrar a relação 
entre algo que é da ordem da desestabilização (o acontecimento histórico) e algo que é, em alguma medida, da ordem da estabilização (a memória).

$\mathrm{Na}$ continuidade do texto, o autor discute o papel da memória, mostrando como essa pode ser vista a partir de diferentes perspectivas, sempre na relação entre certa estabilidade, como, por exemplo, a estabilidade da língua, que está relacionada ao campo dos estudos linguísticos, e certa desestabilização, ligada à interpretação, à linguagem, ao simbólico e também à simbolização. É a partir desse jogo entre aquilo que é estável e aquilo que tende a uma constante desestabilização que Pêcheux defende a existência de uma tensão contraditória "no processo de inscrição do acontecimento no espaço da memória" (PÊCHEUX, 1999, p. 50). Ainda segundo o referido autor, essa tensão se marca por uma dupla forma limite que está na base da relação entre memória e acontecimento, conforme Pêcheux "o acontecimento que escapa à inscrição, que não chega a se inscrever; o acontecimento que é absorvido na memória, como se não tivesse ocorrido (PÊCHEUX, 1999, p. 50).”

Essa relação contraditória mostra que a memória não é "plana", tampouco "fechada", ela é "reavivada" por meio dos “implícitos". Não há, ainda segundo o conceito de memória de Pêcheux, uma memória homogênea, na qual haja apenas uma forma de interpretação. Assim, em relação ao instituto da delação premiada, podemos afirmar que, em sua constituição, há, parafraseando Pêcheux, uma relação contraditória e cumulativa entre as diferentes formas de aferição da verdade ligadas ao campo jurídico. Isso porque, nas palavras do referido autor:

[...] uma memória não poderia ser concebida como uma esfera plena, cujas bordas seriam transcendentais históricos e cujo conteúdo seria um sentido homogêneo, acumulado ao modo de um reservatório: é necessariamente um espaço móvel de divisões, de disjunções, de deslocamentos e de retomadas, de conflitos de regularização... um espaço de desdobramentos, réplicas, polêmicas e contra discursos (PÊCHEUX, 1999, p. 56).

Para análise que propomos aqui, buscamos relacionar esse conceito de memória discursiva apresentado por Pêcheux, no livro anteriormente citado ${ }^{4}$, com o conceito de discurso, definido no livro $O$ discurso: estrutura ou acontecimento. Nesse livro, o discurso é visto como a relação entre algo que é da ordem do logicamente estabilizado

\footnotetext{
${ }^{4}$ Salientamos que o conceito "memória discursiva" foi cunhado por Courtine (2009), a partir do deslocamento conceitual feito em relação à noção de memória, a qual está, em alguma medida, vinculada ao conceito de campo associado ou domínio de memória de Foucault.
} 
e, portanto, da estrutura; e algo que é da ordem do irremediavelmente equívoco, e portando da ordem do acontecimento. Ainda segundo Pêcheux, há em nossa sociedade o que ele chama de espaços discursivos "logicamente estabilizados", nos quais existe uma espécie de "proibição de interpretação", pois eles se fundamentam no "uso regulado de proposições lógicas (Verdadeiro ou Falso)" (PÊCHEUX, 1990, p. 31). Mas, ainda segundo o referido autor, essa suposta homogeneidade lógica é atravessada por aquilo que é da ordem do irremediavelmente equívoco. Esses espaços irremediavelmente equívocos estão intrinsecamente relacionados ao real, definido por Pêcheux como: “pontos de impossível, determinando aquilo que não pode não ser 'assim”" (PÊCHEUX, 1990, p. 29).

Na continuidade do texto, Pêcheux mostra que, para se considerar de forma responsável, a relação entres os espaços logicamente estabilizados e os espaços irremediavelmente equívocos, há certo número de exigências teórico-metodológicas que precisam ser atendidas. A primeira exigência é "dar o primado aos gestos de descrição das materialidades discursivas" (PÊCHEUX, 1990, p. 50), o que, no caso deste trabalho, consiste em priorizar a descrição das leis que, em alguma medida, remetem ao instituto da delação premiada. A segunda exigência consiste em reconhecer que "toda descrição está constitutivamente exposta ao equívoco da língua" (PÊCHEUX, 1990, p. 53), estando aberta, portanto, à falha e ao equívoco e também às possíveis diferentes interpretações das leis; e a terceira exigência fundamenta-se no reconhecimento de que todo discurso "marca a possibilidade de uma desestruturação-reestruturação das redes e trajetos" (PÊCHEUX, 1990, p. 56), o que se vincula à relação entre memória e atualidade, já que, ainda segundo Pêcheux (1990), o acontecimento pode ser definido como o ponto de encontro de uma atualidade e uma memória (PÊCHEUX, 1990, p. 17). Nesse caso, a desestruturação-reestruturação ocorre justamente no/pelo acontecimento. Em relação às leis aqui analisadas, cada lei funciona como um texto "que surge como um acontecimento a ler" (PÊCHEUX, 1999, p. 52) e que, portanto, pode ser interpretado com base no jogo entre memória e atualidade.

Assim, a partir da relação entre esses dois textos (PÊCHEUX, 1990; 1999) e entre os pressupostos teóricos neles apresentados, analisamos, neste tópico, as leis que tratam, em alguma medida, do instituto da delação premiada, a fim de mostrar os deslizamentos de sentido que ocorrem tanto no que diz respeito à constituição histórica 
do referido instituto, quanto em relação aos efeitos de sentido que emergem dessas leis no que diz respeito à figura do delator. Para tanto, verificamos de que maneira as diferentes formas de aferição da verdade judicial são retomadas nas/pelas leis brasileiras.

\section{Análise da delação premiada nas leis brasileiras}

Para análise que passamos a apresentar, adotamos as seguintes etapas de trabalho: i) coletamos, selecionamos e catalogamos as leis que tratam da delação premiada, a fim de mostrar até que ponto o referido instituto jurídico funciona como uma forma de obtenção da verdade; ii) em seguida, procedemos à análise das leis selecionadas e catalogadas, relacionando-as às formas de aferição da verdade apresentadas por Foucault. A partir de tal comparação, foi-nos possível constatar de que forma as leis que tratam da colaboração/delação premiada vão sendo retomadas, com base em um jogo entre memória e atualidade, assim como propõe Pêcheux (1990; 1999), quando trata, como vimos anteriormente, do funcionamento da memória discursiva. Além dessa análise propriamente discursiva, recorremos a textos do direito e, mais precisamente, do direito penal.

No âmbito do referido direito, existe uma classificação de sujeitos no crime. Aquele que cometeu a infração é definido como sujeito ativo e o que sofreu a infração como sujeito passivo. No que se refere à delação premiada, o delator é apresentado pela lei como o ativo, participante, associado, coautor, beneficiado, indiciado, acusado, etc. Todas essas nomeações dizem respeito às relações entre as condições de possibilidade da contemporaneidade e as verdades que constituem esse momento histórico, o qual se constitui com base em relações de saber-poder. É isso o que mostramos nas análises das leis.

No Brasil, a Delação Premiada teve início com a Lei dos Crimes Hediondos, Lei $\mathrm{n}^{\circ}$ 8.072/90, art. 8. ${ }^{\circ}, \S$ Único, e posteriormente o instituto encontra-se previsto em diversos instrumentos legais. Na Lei $\mathrm{n}^{\circ}$ 8.072, de 25, de julho de 1990, que dispõe sobre os crimes hediondos, em seu artigo $8^{\circ}, \S$ único, o delator é tratado como sujeito participante e associado, como vemos a seguir: "o participante e o associado que denunciar à autoridade o bando ou quadrilha, possibilitando seu desmantelamento, terá a pena reduzida de um a dois terços". 
No parágrafo do artigo acima citado, as expressões referenciais definidas "o participante" e "o associado" vinculam o delator ao "bando" ou à "quadrilha" que será delatada. Nesse caso, o delator é alguém ligado ao ato delituoso. As palavras usadas para referir tanto o delator quanto o grupo que realiza e/ou realizou o ato delituoso remetem a uma memória segundo a qual o crime cometido faz parte de um esquema maior, que envolve várias pessoas e que se vincula a uma espécie de organização criminosa. Essa memória vincula-se a um saber-poder sobre o crime organizado, o qual produz verdades que se materializam nas escolhas lexicais, como, por exemplo, como vimos, nas palavras que designam tanto o delator quando o grupo do qual ele faz (fez) parte. É esse saber que permite dizer que não se trata de um crime isolado, mas de uma rede de crimes, vinculados a um grupo de pessoas que se associa e se organiza para poder cometê-los. Há, aqui, um jogo entre a memória de crimes realizados por grandes grupos e/ou organizações criminosas, como é o caso da Máfia Italiana, e a atualidade de crimes, ocorridos no Brasil, que também articulam várias pessoas, vinculadas, na maioria das vezes, a diferentes instâncias públicas e/ou privadas, a exemplo do que ocorre nos crimes que envolvem corrupção de agentes públicos.

A delação premiada também aparece tipificada no artigo $159, \S 4^{\circ}$, do Código Penal brasileiro. Nesse caso, o delator é tratado como "concorrente", como podemos verificar, no " $\$ 4^{\circ}$ - Lei dos Crimes contra o Sistema Financeiro Nacional - n $7.492 / 86$ (art. $25, \S 2^{\circ}$ ), se o crime é cometido em concurso, o concorrente que o denunciar à autoridade, facilitando a libertação do sequiestrado, terá sua pena reduzida de um a dois terços". O efeito de sentido de "concorrente" remete ao responsável penal pelo delito. Em um delito, com concurso de agentes, existe a participação do partícipe e do coautor. O coautor realiza o núcleo verbal da ação criminosa, como subtrair, transportar, portar, violar, falsificar, favorecer, fraudar, entre outros tantos mais especificados nos artigos do Código Penal. Já, o partícipe não realiza o núcleo verbal, porém contribui para o resultado da ação delituosa, como, por exemplo, quando facilita a entrada de assaltantes em uma agência bancária. Ambos são concorrentes, ambos são responsáveis penalmente. Essas nomeações (coautor e partícipe) também se vinculam a um saberpoder acerca dos crimes contra o Sistema Financeiro, os quais estão ligados, por uma ação da memória sobre a atualidade, aos crimes hediondos. Trata-se, portanto, de uma rede de relações, a qual permite a constituição de diferentes verdades. 
Quando verificamos a Lei dos Crimes contra o Sistema Financeiro Nacional $-\mathrm{n}^{\circ}$ $7.492 / 86$, em seu artigo $25, \S 2^{\circ}$, é possível identificar o sujeito delator como coautor ou partícipe. É o que vemos no parágrafo segundo, “§ $2^{\circ}$ Nos crimes previstos nesta Lei, cometidos em quadrilha ou coautoria, o coautor ou partícipe que através de confissão espontânea revelar à autoridade policial ou judicial toda a trama delituosa terá a sua pena reduzida de um a dois terços".

Nesse caso, os termos utilizados (coautor ou partícipe) vinculam-se tanto ao termo "crime" quanto à explicativa "cometidos em quadrilha ou coautoria". Assim como ocorre na Lei no 8.072, de 25 de julho de 1990, a palavra "quadrilha" faz emergir uma memória segundo a qual existe um grupo organizado que se especializou na realização de ações criminosas. Além disso, o termo "coautoria", que aparece como uma outra opção tanto para nomear o agente (coautor) quanto para especificar o tipo de crime (cometido em coautoria), remete, segundo Foucault (2002), à noção de responsabilidade, pois o autor é o responsável legal pelo que ele escreve ou produz. No caso, o autor do crime é aquele que executa o delito. Dessa forma, há uma memória que vincula a noção de autor, seja de um livro ou de um ato, ao conceito de responsabilidade. No caso em tela, o coautor não é visto como o líder da quadrilha, por isso ele não é o autor, mas um dos envolvidos. Assim, vemos, mais uma vez, o efeito da memória sobre a atualidade, pois a forma como a lei é redigida mostra que o coautor não é o líder da quadrilha e, portanto, não é o autor principal do crime. Ele é apenas alguém que participa do crime, assumindo um papel secundário (de coautoria) e, também por isso, pode ser um delator.

Na Lei dos Crimes contra a Ordem Tributária e Econômica - n $^{\circ} 8.137 / 90$, em seu artigo $16^{\circ}$, $\S$ único, o papel de delator é conferido a qualquer pessoa, como lemos a seguir: “Art. 16. Qualquer pessoa poderá provocar a iniciativa do Ministério Público nos crimes descritos nesta lei, fornecendo-lhe por escrito informações sobre o fato e a autoria, bem como indicando o tempo, o lugar e os elementos de convicção".

Aqui, há uma espécie de desvinculação entre o delator e o autor, pois o delator é nomeado como "qualquer pessoa" que provoque a ação do Ministério Público, fornecendo informações sobre "o fato e a autoria". Há, portanto, de um lado o delator e de outro o autor. Vemos, então, que o delator, na Lei dos Crimes contra a Ordem Tributária, não é coautor, mas alguém que tem acesso aos crimes e resolve denunciá-los 
ao Ministério Público. Contudo, devido, mais uma vez, a ação da memória sobre a atualidade, constatamos que esse tipo de delator (o que não tem vinculação com o crime) não é o mesmo que emerge dos escândalos de corrupção discursivizados na/pela mídia nos últimos tempos. Os delatores do caso de corrupção da Petrobrás (conhecido como Petrolão), por exemplo, são todos, até agora, envolvidos nos crimes sobre os quais fazem suas delações. E é justamente isso que caracteriza a "delação premiada", pois o prêmio concedido ao delator é o abrandamento, a redução ou mesmo a suspensão da pena que lhe seria imputada pelo fato de ele ser um coautor do ato delituoso que está sendo investigado.

É por isso que na Lei $n^{\circ}$ 9.807, de 13 de julho de 1999, nos artigos 13,14 e 15, a figura do delator é vista como acusado, beneficiado, indiciado e colaborador.

\section{DA PROTEÇÃO AOS RÉUS COLABORADORES}

Art. 13. Poderá o juiz, de ofício ou a requerimento das partes, conceder o perdão judicial e a conseqüente extinção da punibilidade ao acusado que, sendo primário, tenha colaborado efetiva e voluntariamente com a investigação e o processo criminal, desde que dessa colaboração tenha resultado:

I - a identificação dos demais co-autores ou partícipes da ação criminosa;

II - a localização da vítima com a sua integridade física preservada;

III - a recuperação total ou parcial do produto do crime.

Parágrafo único. A concessão do perdão judicial levará em conta a personalidade do beneficiado e a natureza, circunstâncias, gravidade e repercussão social do fato criminoso.

Art. 14. O indiciado ou acusado que colaborar voluntariamente com a investigação policial e o processo criminal na identificação dos demais coautores ou partícipes do crime, na localização da vítima com vida e na recuperação total ou parcial do produto do crime, no caso de condenação, terá pena reduzida de um a dois terços.

Art. 15. Serão aplicadas em benefício do colaborador, na prisão ou fora dela, medidas especiais de segurança e proteção a sua integridade física, considerando ameaça ou coação eventual ou efetiva (grifamos).

Quando essa Lei trata do termo beneficiado, ela retoma um efeito de sentido segundo o qual o indivíduo é analisado para poder obter o benefício. Tal análise considera a personalidade do referido indivíduo e também a repercussão social gerada pelo delito praticado por ele.

No que diz respeito aos colaboradores, nessa Lei, eles são discursivizados como aqueles que fornecem informações importantes para as investigações do crime. Portanto, quando esses delatores ofertam pistas, que são verificadas e consideradas como verdadeiras, a respeito do fato delituoso, eles passam a necessitar de uma proteção 
e de uma determinada segurança, pois não querem estar sujeitos a possíveis retaliações de seus comparsas ou mesmo da própria população. Dessa forma, a proteção aos colaboradores é um ponto encontrado em algumas leis que tratam da delação premiada, pois funciona como medida de proteção à integridade física dos delatores. No artigo 15, acima citado, é apresentada uma maneira encontrada pelo legislador para proteger o colaborador.

A importância dessa proteção aos delatores, descrita na lei acima citada, remete à memória do Omertá, que significa humilde na língua napolitana. Omertá era um voto de silêncio inquebrável que existia entre os mafiosos; para eles esse voto funcionava como uma lei $^{5}$. Esse voto surgiu na máfia siciliana, por volta do século XIX, quando ocorria uma perversa punição aos traidores que, de alguma maneira, ousavam colaborar com a polícia ou com o governo, fornecendo algum tipo de informação. Na Itália, essa Lei do silêncio tornou-se a mais poderosa em toda máfia italiana e, posteriormente, se universalizou. Aquele que desrespeitasse a referida lei era automaticamente assassinado pela organização criminosa. Nesse período, ser um delator era ser um indivíduo morto. Não existiam proteções contra a pena de morte aplicada por essa máfia àquele que quebrasse o voto do silêncio.

Esse temor ao ato de testemunhar foi com o tempo e com as devidas proteções da Lei sendo amenizado. Atualmente, ainda existe esse medo de colaborar com a justiça, mas, com o surgimento das devidas proteções aos colaboradores, colabora-se muito mais, pois o delator sente-se mais seguro.

Quantos ao termo “indiciado”, esse representa um indivíduo que, em princípio, é considerado apenas como suspeito por existirem indícios de que ele cometeu determinado crime. Já o termo "acusado" nomeia um indivíduo que responde por um processo judicial. Esses dois termos geralmente referem-se a uma mesma pessoa, em momentos distintos, pois todo acusado já foi um dia indiciado. Isso produz um efeito da memória sobre a atualidade, pois aquele que é ainda indiciado é, muitas vezes, discursivizado como se fora já acusado. A mídia é uma das maiores responsáveis pela espetacularização da investigação policial e pela consequente transformação do indiciado em acusado, mesmo quando, judicialmente, ainda não houve essa mudança. $\mathrm{O}$ indiciado é aquele que é investigado durante o inquérito policial, sendo o mesmo

\footnotetext{
${ }^{5}$ Máfia é uma organização criminosa e a palavra foi retirada do adjetivo siciliano "mafiusu" que significa "alarde agressivo, bravo".
} 
formalizado pelo delegado de polícia, tendo como fundamento evidências e indícios colhidos pelos meios de provas, como depoimentos, laudos periciais e/ou escutas telefônicas. Quando o inquérito é concluído, esse é encaminhado ao Ministério Público, que, a partir de então, passa a analisar se realmente existem provas contra o indiciado. Uma vez que o Ministério Público, que é representado pelo promotor de justiça, considera a existência de provas, ele apresenta denúncia à justiça. A partir do momento que o judiciário aceita a denúncia formulada pelo Ministério Público, o indiciado passa para condição de réu e assim é considerado como acusado e processado por um suposto crime.

Tanto para o indiciado quanto para o acusado é concedida a oportunidade de colaborar voluntariamente com a investigação policial e, assim, obter redução da pena, conforme descrito no artigo 14 acima citado. Assim, tanto o indiciado quanto o acusado podem ser delatores, uma vez que a delação premiada pode ocorrer tanto na fase inquisitorial quanto na fase processual.

Voltando à questão da proteção ao delator, verificamos que, na Lei $\mathrm{n}^{\circ} 12.850$, de 2 de agosto de 2013, também aparece uma forma de proteção ao delator quando, no inciso VI do artigo $5^{\circ}$, surge a possibilidade de o delator "cumprir pena em estabelecimento penal diverso dos demais corréus ou condenados". Aqui, emerge uma memória segundo a qual o delator é um traidor e, por isso, deve ser mantido à distância dos demais corréus, para não sofrer retaliações e para proteger sua integridade física. Além disso, assim como em outras Leis, o delator aparece como alguém que não se identifica com os demais réus, como uma exceção, como alguém que faz parte, mas, ao mesmo tempo, está à parte. Esse efeito de verdade que permite que o delator seja categorizado como uma espécie de traidor remete a outros momentos históricos, como, por exemplo, a Inconfidência Mineira, quando Joaquim Silvério dos Reis delatou o grupo de inconfidentes e entrou para história como sendo um traidor. O que mostra que a história é, como defende Foucault, descontínua.

Ainda sobre a Lei 12.850, de 2 de agosto de 2013, a delação premiada é apresentada no capítulo II, seção I da referida lei. No referido capítulo, fica estabelecida a maneira como deve ocorrer a investigação e os meios de obtenção de provas. Entre esses meios, está o da colaboração premiada. Nessa lei, o delator é visto como agente 
colaborador e beneficiado. Vejamos, então, alguns trechos, tanto do Art. $4^{\circ}$. quanto do Art. $5^{\circ}$, pois esse último trata dos "direitos do colaborador":

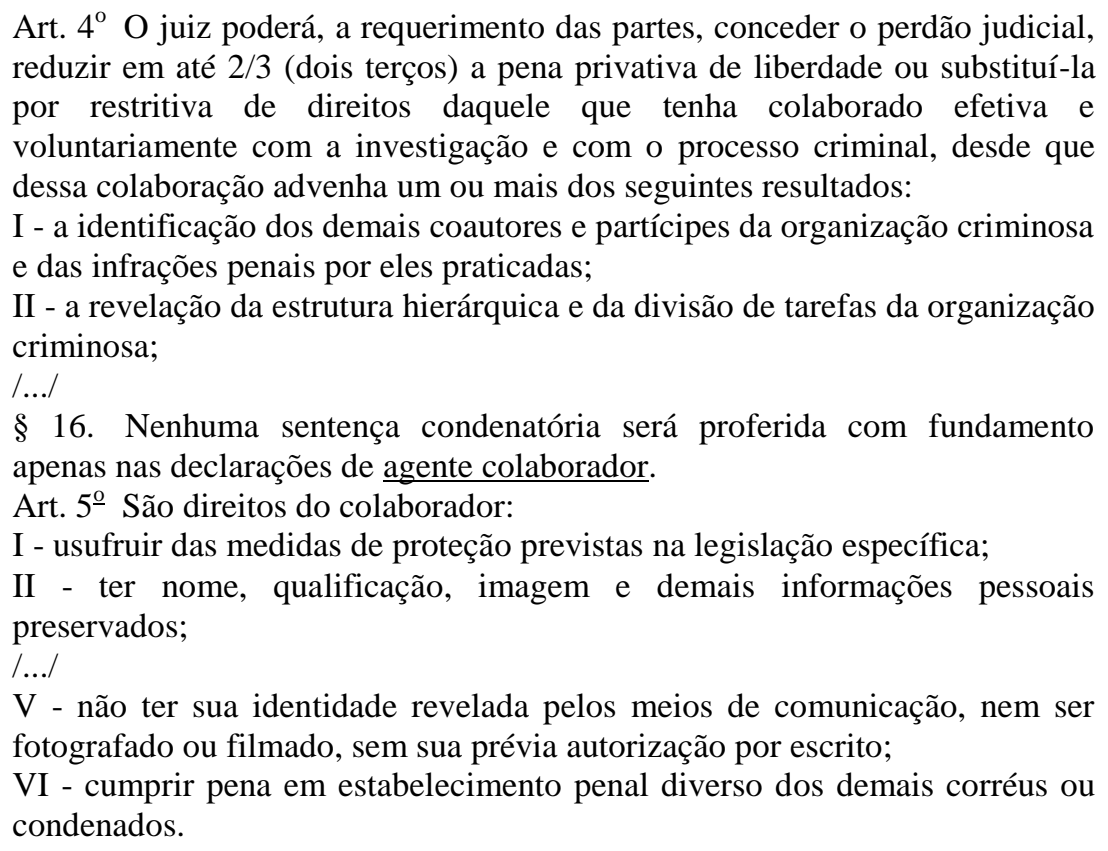

Nessa Lei, o termo colaborador é relacionado ao do sujeito que tem o direito de ser assistido por um defensor nos atos das negociações judiciais, uma vez que ele não pode ser privado de sua defesa para que não acorra nenhum tipo de coação durante as negociações. Portanto, aqui, o termo colaborador desliza para o efeito de alguém que necessita de amparo, de ajuda, de proteção durante os tramites judiciais. Trata-se de um outro efeito de verdade, o qual também remete a certa memória acerca do delator, que é apresentado, nesse caso, como alguém que precisa de ajuda e não mais como um traidor. Trata-se, portanto, da constituição de diferentes efeitos de verdade, todos relacionados entre si, devido ao funcionamento da memória discursiva.

Na nova Lei de Drogas - $\mathrm{n}^{\circ} 11.343 / 06$, em seu artigo 41, o delator aparece, mais uma vez como indiciado ou acusado:

Art. 41. O indiciado ou acusado que colaborar voluntariamente com a investigação policial e o processo criminal na identificação dos demais coautores ou partícipes do crime e na recuperação total ou parcial do produto do crime, no caso de condenação, terá pena reduzida de um terço a dois terços.

Os termos indiciado e acusado funcionam, no artigo 41, com efeitos de sentido equivalentes. Isso ocorre devido ao uso do operador "ou", pois a alternância que ele 
indica pode ser interpretada como incidindo sobre o sujeito nomeado (aquele que foi indiciado ou aquele que foi acusado, que são, nesse caso, sujeitos distintos), mas também pode incidir sobre a própria nomeação (ou seja, aquele que pode ser chamado de indiciado ou de acusado). Essas duas situações podem ser explicadas por meio daquilo que Pêcheux (1993) chama de efeito metafórico. No primeiro caso, indiciado (X) e acusado (Y) não são substituíveis, no contexto judiciário, pois, como explicamos acima, o indiciado é aquele que ainda não é réu, afinal não há ainda processo, mas apenas inquérito. Já o acusado é o réu, pois, nesse segundo momento, o processo judiciário já foi instaurado pelo juiz, que aceitou a denúncia do promotor. No segundo caso, indiciado e acusado são substituíveis. Há vários contextos em que essa substituição é possível. Isso ocorre, por exemplo, na mídia, quando esta espetaculariza um determinado escândalo de corrupção, deixando a ver o indiciado como que ocupando a posição de acusado. Ainda segundo Pêcheux (1993):

\begin{abstract}
Chamaremos de efeito metafórico o fenômeno semântico produzido por uma substituição contextual para lembrar que esse "deslizamento de sentido" entre $\mathrm{x}$ e y é constitutivo do "sentido" designado por $\mathrm{x}$ e y; esse efeito é característico dos sistemas lingüísticos "naturais", por oposição aos códigos e às "línguas artificicias", em que o sentido é fixado em relação a uma metalíngua "natural": em outros termos, um sistema "natural" não comporta uma metalíngua a partir da qual seus termos poderiam se definir: ele é por si mesmo sua própria metalíngua (PÊCHEUX, 1993, p. 96)
\end{abstract}

Esse conceito de efeito metafórico, quando relacionado àquilo que Pêcheux defende no livro $O$ discurso: estrutura ou acontecimento, possibilita-nos pensar nas leis como elaboradas a partir de uma relação entre o logicamente estabilizado, ou seja, aquilo que se filia a certa uniformidade lógico-formal; e o irremediavelmente equívoco, que diz respeito a "objetos, cujo modo de existência parece regido pela própria maneira com que falamos deles" (PÊCHEUX, 1990, p. 28). Nesse caso, o Art. 41, da Lei ${ }^{\circ}$ 11.343/06, remete ao que já foi estabelecido, nas demais leis, acerca do sentido de indiciado e do de acusado. Mas, para além dessa suposta uniformidade lógica, estabelecida no/pelo direito positivado, existem outras possibilidades de interpretação, as quais filiam-se a outras memórias e, portanto, a outras redes e trajetos interpretativos, como, por exemplo, aqueles materializados na/pela mídia. 
O termo "colaborador" volta a aparecer na recente lei, que trata do Sistema Brasileiro de Defesa da Concorrência - lei $\mathrm{n}^{\mathrm{o}}$ 12.529/2011, em seu artigo 86, como mostramos a seguir:

\footnotetext{
Art. 86. O Cade, por intermédio da Superintendência-Geral, poderá celebrar acordo de leniência, com a extinção da ação punitiva da administração pública ou a redução de 1 (um) a $2 / 3$ (dois terços) da penalidade aplicável, nos termos deste artigo, com pessoas físicas e jurídicas que forem autoras de infração à ordem econômica, desde que colaborem efetivamente com as investigações e o processo administrativo e que dessa colaboração resulte:

I - a identificação dos demais envolvidos na infração; e

II - a obtenção de informações e documentos que comprovem a infração noticiada ou sob investigação.

$\S 8^{\circ}$ Na hipótese do $\S 7^{0}$ deste artigo, o infrator se beneficiará da redução de $1 / 3$ (um terço) da pena que lhe for aplicável naquele processo, sem prejuízo da obtenção dos benefícios de que trata o inciso I do $\S 4^{\circ}$ deste artigo em relação à nova infração denunciada (grifamos).
}

Nesse caso, o autor da infração pode até colaborar com as investigações, mas continua sendo nomeado como "infrator". Isso mostra que, nessa lei, a colaboração é uma condição (desde que colaborem) que pode reduzir ou, até mesmo, extinguir a penalidade aplicável ao infrator, mas não o tira da condição de infrator. Ou seja, o infrator é visto como alguém que pode colaborar, mas isso não o torna um colaborador. Também nesse caso, é possível verificar a relação entre diferentes efeitos de verdade, uma vez que o que faz o colaborador um infrator são as relações de saber-poder da contemporaneidade, as quais articulam-se com a memória discursiva, produzindo "verdades" acerca do lugar de colaborador.

\section{Considerações finais}

Após as análises, podemos afirmar que o instituto negocial penal da delação premiada apresenta-se como um instituto jurídico que, por meio das informações dos delatores, funciona como uma forma de obtenção da verdade. Na retomada do texto $A$ verdade e as formas jurídicas, de Foucault, mostramos a constituição descontínua de diferentes formas de obtenção da verdade jurídica na história. No referido livro, verificamos que o instituto da delação premiada está associado tanto ao inquérito quanto ao exame, formas de aferição da verdade que passaram por várias (re)configurações até chegarem a seu formato atual. Constatamos, assim, que a delação premiada, quando associada ao inquérito e ao exame, permite dizer muito sobre o funcionamento da 
sociedade, bem como sobre as relações poder-saber que se estabelecem na contemporaneidade.

$\mathrm{Na}$ análise das leis, ao recorrermos ao conceito de memória discursiva, mostramos como a figura do delator foi sendo construída e reconstruída por meio de um jogo entre memória e atualidade. Nessa análise, verificamos as diferentes nomeações por meio das quais a figura do delator é apresentada nas leis que tratam da delação premiada, mostrando a existência dos deslizamentos de sentido em cada lei brasileira que trata do referido instituto. Assim, foi possível concluir que um mesmo termo pode ter diferentes efeitos de sentido e pode deslizar para diferentes interpretações. É o que ocorre com o termo "delator", que, nas leis analisadas, aparece tanto como "colaborador" quanto como "indiciado" e/ou "acusado". Isso mostra que a condição de colaborador não apaga o lugar de "infrator", mas que essas duas posições de sujeito funcionam nas leis contemporâneas brasileiras, constituindo os sentidos que circulam acerca do instituto da delação premiada.

\section{REFERÊNCIAS}

BRASIL. Código Penal e Constituição Federal. 21. ed. São Paulo: Saraiva, 2015.

BRASIL. Lei n. $^{\circ}$ 7.492, de 16 de junho de 1986. Diário Oficial [da] República Federativa do Brasil, Brasília, DF, 16. jun. 1986.

BRASIL. Lei $n^{\circ}$ 8.072, de 25 de julho de 1990. Diário Oficial [da] República Federativa do Brasil, Brasília, DF, 25. dez. 1990.

BRASIL. Lei $n^{\circ}$ 8.137, de 27 de dezembro de 1990. Diário Oficial [da] República Federativa do Brasil, Brasília, DF, 27. dez. 1990.

BRASIL. Lei n. ${ }^{\circ}$ 9.807, de 13 de julho de 1999. Diário Oficial [da] República Federativa do Brasil, Brasília, DF,13. jul. 1999.

BRASIL. Lei $n .^{o} 11.343$, de 23 de agosto de 2006. Diário Oficial [da] República Federativa do Brasil, Brasília, DF, 23 agosto. 2006.

BRASIL. Lei $n .^{\circ}$ 12.529, de 30 de novembro de 2011. Diário Oficial [da] República Federativa do Brasil, Brasília, DF, 30 novembro. 2011.

BRASIL. Lei $n^{\circ}$ 12.850, de 2 de agosto de 2013. Diário Oficial [da] República Federativa do Brasil, Brasília, DF, 2. Agosto. 2013. 
CAPEZ, F. Curso de Direito Penal - legislação penal especial. São Paulo: Saraiva, 2010.

COURTINE, Jean-Jacques. Análise do discurso político: o discurso comunista endereçado aos cristãos. São Carlos, SP: EdUFSCar, 2009.

FOUCAULT, Michel. A verdade e as formas jurídicas. São Paulo: Editora NAU, $4^{\mathrm{a}}$ edição, 2002 [1973].

FOUCAULT, M. Retornar à história. In: MOTTA, M. de B. (org.) Ditos e Escritos II: arqueologia das ciências e história dos sistemas de pensamento. Trad. Elisa Monteiro. Rio de Janeiro: Forense Universitária, 2005 [1972], p. 282-295.

FOUCAULT, M. Poder e Saber. In: MOTTA, M. de B. (org.) Ditos e Escritos IV: estratégia, poder-saber. Trad. Vera Lucia Avellar Ribeiro. Rio de Janeiro: Forense Universitária, 2006 [1977], p. 223-240.

MOSSIN, H. A.; MOSSIN, J. C. O. G. Delação premiada: aspectos Jurídicos. São Paulo: Ed. JH. Mizuno, 2016.

PÊCHEUX, M. O discurso: estrutura ou acontecimento. Campinas: Pontes, 1990 [1983].

PÊCHEUX, M. Análise Automática do Discurso (AAD-69). In: GADET, F; HAK, T. Por uma análise automática do discurso: uma introdução à obra de Michel Pêcheux. Campinas/SP: Editora da UNICAMP, 1993. p. 61-161

PÊCHEUX, M. Papel da memória. In: ACHARD, P. et al (Org.). Papel da memória. Tradução de José Horta Nunes. Campinas: Pontes, 1999 [1983b], p. 49-57. 